\title{
EXAMINATION OF MYCOLOGICAL SAMPLES BY MEANS OF THE SCANNING ELECTRON MICROSCOPE
}

\author{
M. Thibaut and M. Ansel
}

\begin{abstract}
Three species of Siphomycetes: Rhizopus arhizus, Rhizopus equinus and Rhizopus nigricans, as well as a Septomycete: Emericella nidulans, have been examined by means of a scanning electron microscope. Among the different Rhizopus, this technique showed differences in the appearance of the sporangia. In Emericella nidulans, scanning microscopy enabled one to ascertain that the "Hull cells" were completely hollow and also demonstrated the ornemented aspect of the ascospores.
\end{abstract}

\section{INTRODUCTION.}

Scanning electron microscopy makes the direct examination of surfaces possible and gives three dimensional images and a great depth of field. After having described this technique, we give a few examples which illustrate the advantage of this method for studying fungi.

\section{MATERIAL AND TECHNIQUES.}

The species examined belong to the Siphomycetes and Septomycetes. These were on the one hand Rhizopus arhizus, Rhizopus equinus, and Rhizopus nigricans, and on the other Emericella nidulans. Samples of the different species were first fixed by formaldehyde vapours and transported on small copper cylinders which were subsequently placed in a carbon eva- porator. They are first of all covered with a thin film of carbon, and then receive a fine spray of gold. The samples are then examined with the scanning electron microscope J.S.M. U 3 Jeol, using acceleration voltages of between 15 and 25 kilovolts. The image produced by the secondary electrons are then photcgraphed.

\section{RESULTS.}

Among the Siphomycetes, fungi having a relatively voluminous thallus, the genus Rhizopus includes a number of species whose identification depends very often on changes in size. In Rhizopus arhizus (Fig. 1), the wall of the sporangium is alvoeolated. Each alveole appears in the form of an independent cup as if pedicellated (Fig. 2). The interior of the small cups of Rhizopus arhizus is not an even surface,

Laboratcire de Parasitologie, 15 rue de l'Ecole de Médecine, 75 - Paris, VI, France. Submitted to publication on 20.11.1972. 
but shows the presence of long folds stretching across the cup from one edge to the other. In Rhizopus equinus (Fig. 3) scanning electron microscopy revealed the alveolated aspect of the outside membranes of the sporangia (Fig. 3). The edges of the alveoles form a sort of continuous network (Fig. 5) and the contours of the alveoles are confluent. Scanning microscopy made it possible to observe the smooth surface and elongated shape of the chlamydospores (Fig. 6). In Rhizopus nigricans, during dehiscence of the sporangium, the latter is emptied of its spores and the walls of the columella cave in and turn inside out (Fig. 7). Numerous spores remain adherent to the smooth surface of the columella (Fig. 8). The spores are ridged, but the ridges running in the longitudinal direction of the spore are nevertheless flexouse. All the ridges seem to end at the poles of the spore, but scanning microscopy did not enable cne to see a germinal pore.

Among the Septomycetes, in the group of Adelomycetes and in certain Ascomycetes, there is a majority of microscopic forms, the tenuous mycelium of which attains very often only $2 \mu$ or even $1 \mu$ in diametre. We observed the sex conceptacles of Emericella nidulans by means of scanning electron microscopy and were able to identify extremely fine and precise formations. The perithecia are surrounded by a layer of outer wall cells or "Hull cells" which were found to consist of a sort of swelling with a smooth surface and which were perfectly hollow (Fig. 9). Inside the perithecia, the disruption of the asci set free the ascosporer the external aspect of which can be described in greater detail (Fig. 10). The latter resemble highly biconvex lentils the edges of which are thin and show two circular raised fringes or equatorial crests separated by a furrow. The internal face of each crest is seen to slant towards the lenticular surface like a series of arches joined together at the top; the pillars of the arches are inseeted in the periphery of the smooth surface (Fig. 11). It sometimes happens that the base of the pillars join together and surround a kind of small pit or fovea (Fig. 12). It is impossible to see these pillars and fovea, by means of an optical microscope, because os their small size. Further- more, the equatorial furrow separating the two crests appears to be subdivided by small, regularly spaced, meridian septa, which transform it into a circular wall of small partitions.

\section{DISCUSSION.}

Scanning electron microscopy techniques appear to be extremely useful, if not indispensable, in Mycology, for the differenciation of different species. The diagnosis of the latter sometimes proves difficult, as it depends mainly on the identification of microscopic characteristics, namely those of the spores. Very often not only the spores, but also the mycelium are only $1 \mu$ to $2 \mu$ in diametre and the finer details are consequently out of the range of the optical microscope. Although the latter has a resolving power as low as $20 \mathrm{~nm}$, i.e. fifteen times more. Furthermore, whereas the optical microscope, when used at its high magnification under oil immersion does not show the spatial arrangement of the elements, the scanning microscope, although it does not give a true image, nevertheless gives a three dimensional picture with a great depth of field and an almost stereoscopic appearance. Optically, images of this type in relief can only be observed by means of stereoscopic binocular lenses, and even then a clear image can only be obtained at a magnification of a hundred. By scanning electron microscopy, a magnification of 10.000 can be obtained which is 100 times more; hence the advantage of using this method for examining fungi.

In mycology, Jones (4) was the first to publish the use of the scanning electron microscope. By means of this technique, Hawker (1) observed the ascospores of several species of Elaphomyces; Old and Robertson (7) studied the conidia of $\mathrm{Co}$ chlibolus sativus; Reisinger and Mangenot (9) examined the morphology of Dendryphiella vinosa; Perreau and Heim (8) analised the ornementation of various basidiospores; Melendez-Howell and Cailleux (6) described the ascospores of Gelasinospora.

A review of the literature has only revealed the use of the scanning electron microscope for examination of pathogenic 


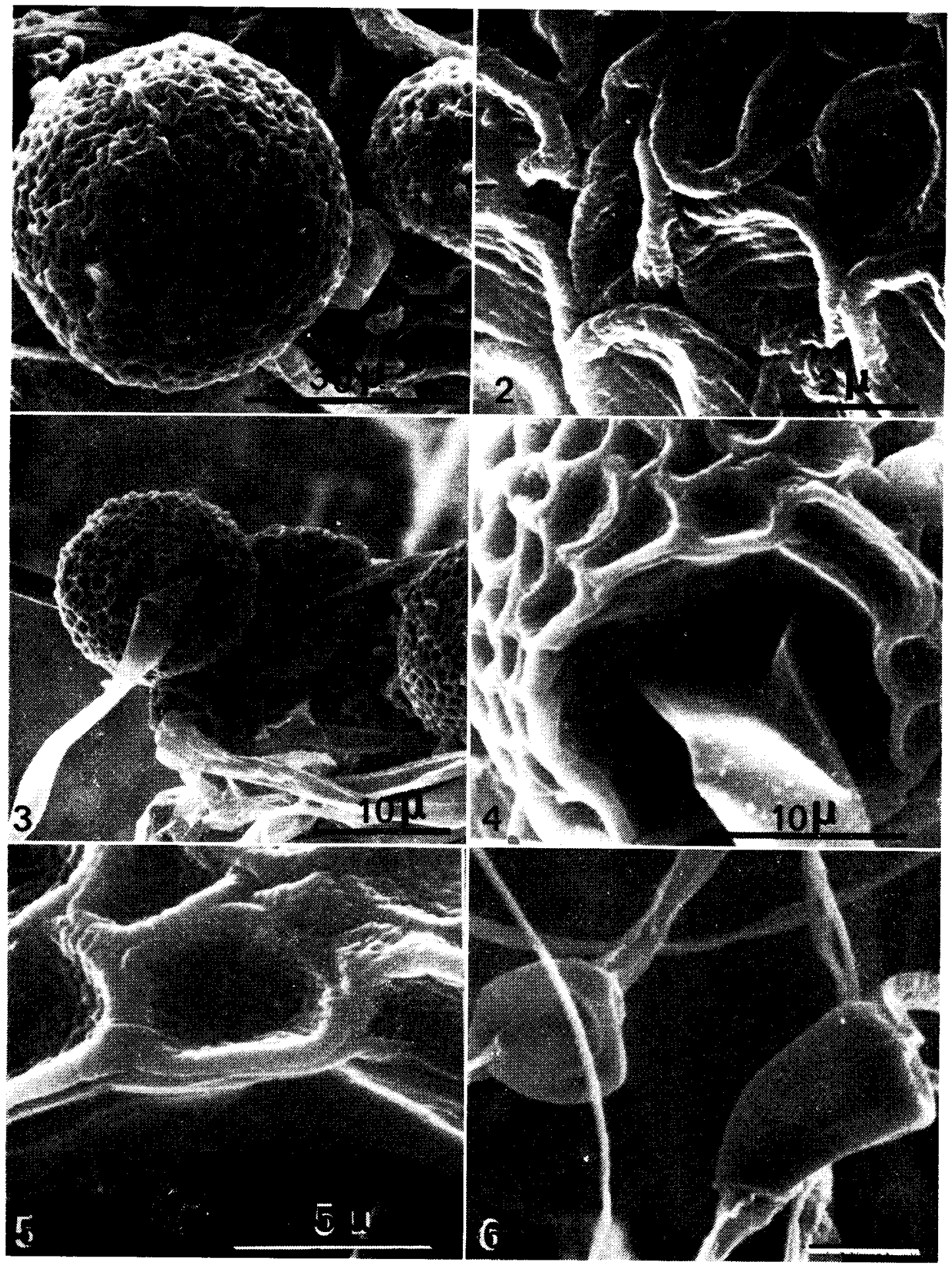




\section{LEGEND OF THE FIGURES.}

Fig. 1. - Rhizopus arhizus. Note the alveolated aspect of the wall of the sporangium.

Fig. 2. - Rhizopus arhizus. Detall of the previous photograph.

Fig. 3. - Sporangia of Rhizopus equinus.

Fig. 4. - Rhizopus equinus. Lower view of the sporangium. Note the alvroles in the external wall.

Fig. 5. - Sporangium of Rhizopus equinus. Detall of the prevlous photograph.

Fig. 6. - Chlamydospores of Rhizcpus equinus. Note their absolutely smooth appearance. 


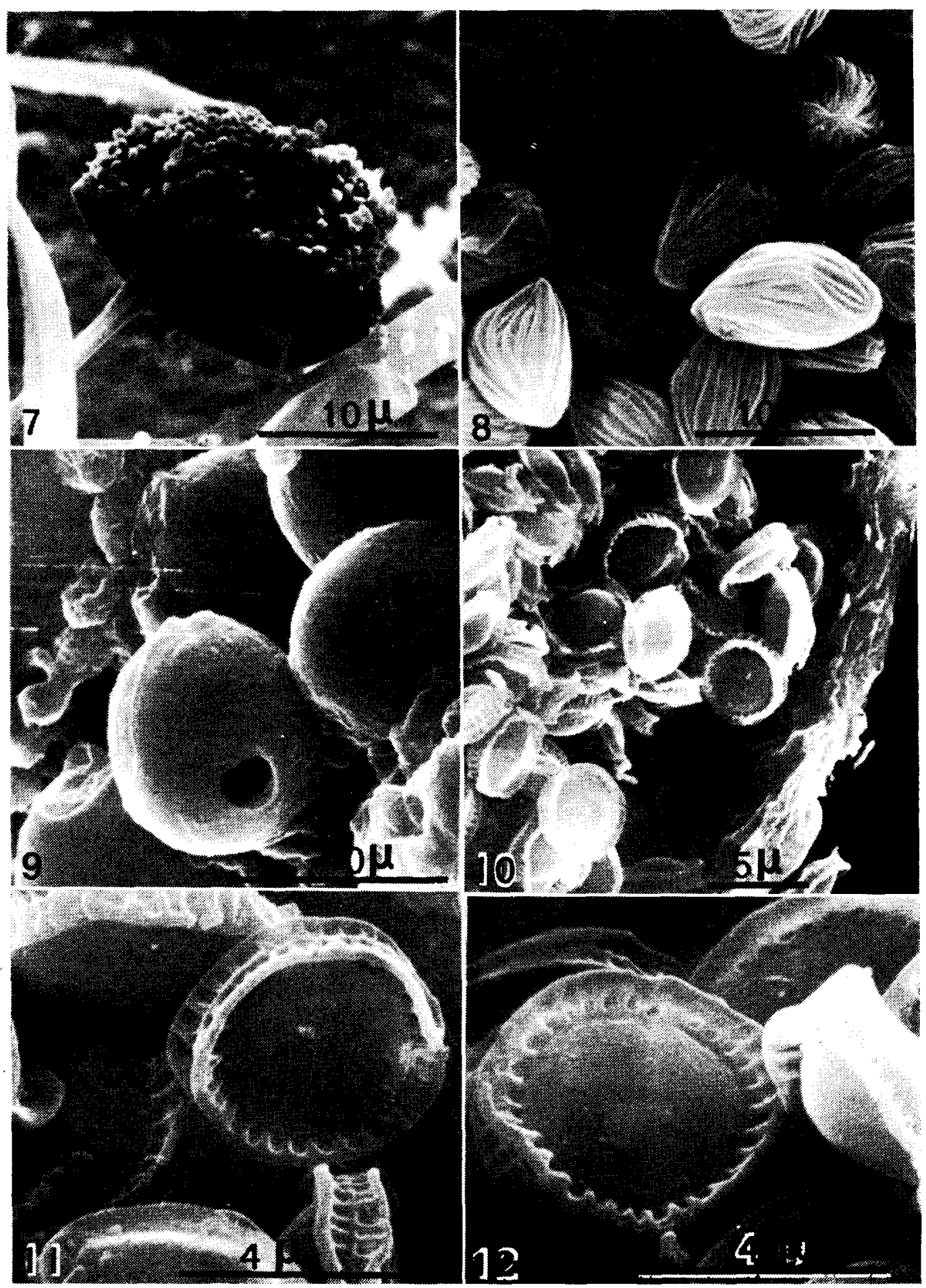


Fig. 7. - Dehiscent sporangium of Rhizopus nigricans.

Fig. 8. - Spores of Rhizopus nigricans, Note their ribbed appearance.

Fig. 9. - Emericella nidulans, Hull cells Note the perforation of one of the Hull cells, showing that these cells are hollow.

Fig. 10. - Ascospores of Emericella nidulans. Note their bivalve shape and ornamented appearance.

Fig. 11, - Ascospores of Emericella nidulans at a higher magnification. Each face is slightly convex. The internal border shows the presence of arches. The external border shows the presence of arches.

Fig, 12, - Upper surface of the ascospore of Emericella niaulans. Already it is possible to see the arches joined together at their base and transformed into a fovea. 
fungi in a few publications. Considering the images reported by Locci (5) who studied Aspergillus amstelodamiby means of scanning microscopy, it seemed to us that the examination of the ascospores of different species of Eurotiaceae might provide finer details in specific descriptions and possibly in the various strains or mutants. Ito and joint authors (3) analysed the surfacce structures of the Dermatophytes belonging to the genus Microsporum, Epidermophyton, Trichophyton. Furthermore, Ito and joint authors (3) also studied by means of this techniques Penicillium chrysogenum, Aspergillus niger, Aspergillus oryzae and Candida utilis, but derived no taxonomic conclusions.

\section{CONCLUSION}

Scanning electron microscopy enables one to observe structures whose size is less than the resolving power of the optical microscope and provides a stereoscopic view of these structures. Thus in several species of Rhizopus, one is able to observe characteristic details which facilitate the differentiation of very close special simply by examination of the aspect of the sporangia. In Septomycetes such as Emericella nidulans, scanning electron microscopy shows, on the one hand, that the "Hull cells" are completely hollow, and on the other, the ornementated aspect of the ascospores.

\section{RESUMO}

Três espécies de Sifomicetas: Rhizopus arhizus, Rhizopus equinus, Rhizopus nigricans e um Septomiceta: Emericella nidulans foram examinados em microscopia de exploração. Esta técnica mostrou detalhes não evidenciáveis ao poder de resolução do microscópio óptico, demonstrando ser útil para o diagnóstico em micologia.

\section{REFERENCES}

1. HAWKER, L. E. - Wall ornamentation of ascospores of species of Elaphomyces as shown by the scanning electron microscope. Trans. Br. Mycol. Soc., 51: 493-498, 1968.

2. ITO, Y., NOZAWA, $Y$., SUSUKI, H. and SETOGUTI, T. - Surfaces structures of Dermatophytes as seen by the scanning electron microscope. Sabouraudia. 7: 270-272, 1970

3. ITO, Y. \& SETOGUTI, T. - Examination of several selected fungi by scanning electron microscope. Mycopath. et Mycol. appl. 41: 299-305, 1970.

4. JONES, D. - Examination of mycological specimens in the scanning electron microscope. Trans. Br. Mycol. Soc. 50: 690-691, 1967.

5. LOCCI, R. - Investigations on fungal features by scanning electron microscopy. I. The life cycle of Aspergillus amstelodami. Riv. Patol. veg. 5: 179195,1969
6. MELENDEZ - HOWELL, L. M. \& CAILLEUX, $\mathbf{R}$. - Problèmes posés par la distinction et la valeur du pore germinatif chez les ascospores fovéolées en microscopie à balayage. Ann. Ss. Nat. Bot. Biol. vég., 10: 339-350, 1969 .

7. OLD, K. M. and ROBERTSON, W. M. Examination of conidia of Cochliobolus sativas recovered from naturals soil using transmission and scanning electron microscopy. Trans. Br. Mycol. Soc. 53: 217-221, 1969.

8. PERREAU, J. \& HEIM, R. - L'ornementation des basidiospores au microscope electronique à balayage. Rev. Mycol. 33: 329-340, 1969.

9. REISINGER, O. \& MANGENOT, F. Analyses morphologiques au microscope electronique à balayage et étude de l'antogénie sporale chez Dendryphiella vinosa (Berk. et Curt.) Reisinger. C. R. Acad. Sci., 269: 18431845,16 . 